運動前のミネラルを含むサプリメント摂取が酸化ストレスマーカーおよび

\author{
糖・脂質代謝に及ぼす影響
}

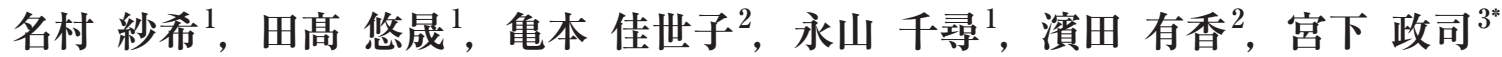

\title{
Effects of pre-exercise mineral-containing supplemention on oxidative stress markers, carbohydrate and lipid metabolism
}

\author{
Saki Namura ${ }^{1}$, Yusei Tataka ${ }^{1}$, Kayoko Kamemoto ${ }^{2}$, Chihiro Nagayama ${ }^{1}$, \\ Yuka Hamada ${ }^{2}$ and Masashi Miyashita ${ }^{3 *}$ \\ ${ }^{1}$ 早稲田大学大学院スポーツ科学研究科, × 359-1192 埼玉県所沢市三ヶ島2-579-15 (Waseda University, Graduate School \\ of Sport Sciences, 2-579-15 Mikajima, Tokorozawa, Saitama 359-1192, Japan) \\ 早稲田大学スポーツ科学研究センター, テ359-1192 埼玉県所沢市三ヶ島 2-579-15 (Waseda University, Waseda Institute \\ for Sport Sciences, 2-579-15 Mikajima, Tokorozawa, Saitama 359-1192, Japan) \\ ${ }^{3}$ 早稲田大学スポーツ科学学術院，７359-1192 埼玉県所沢市三ヶ島2-579-15 (Waseda University, Faculty of Sport Sci- \\ ences, 2-579-15 Mikajima, Tokorozawa, Saitama 359-1192, Japan)
}

Received: May 15, 2020 / Accepted: October 29, 2020

\begin{abstract}
Little is known regarding the effects of mineral-containing supplemention on oxidative stress markers, carbohydrate and lipid metabolism in response to an acute bout of exercise in humans. The present study investigated whether prior mineral-containing supplemention can improve oxidative stress status and how this supplementation influences on carbohydrate and lipid metabolism after a single bout of cycling in young men. Twelve, healthy young men (aged 22.5 \pm 2.4 years, mean $\pm \mathrm{SD}$ ) underwent two, 150-min trials in a random order. Each participant received oral administration of mineral supplement containing $13.4 \mathrm{mg}$ of sulphur or placebo one minute before exercise. In both trials, participants cycled at $75 \%$ of heart rate reserve for 60 minutes and then rested for 90 minutes. Blood samples were collected pre-exercise supplementation, immediately after exercise, 30 minutes after exercise, 60 minutes after exercise and 90 minutes after exercise. Circulating concentrations of derivatives of reactive oxygen metabolites, biological antioxidant potential, glucose and insulin did not differ between trials. Elevated circulating concentrations of non-esterified fatty acids were observed immediately after exercise in the supplementation trial compared with the placebo trial (mean \pm SD: $1.1 \pm$ 0.5 and $0.9 \pm 0.3 \mathrm{mmol} / \mathrm{L}$, respectively: trial $\times$ time interaction, $\mathrm{p}=0.036$ ). The present study showed that acute mineral-containing antioxidant supplemention appears to have no effect on improving oxidative stress markers in response to a single bout of cycling in healthy young men. In addition, the findings of this study suggested that mineral-containing supplemention may influence lipids metabolism during exercise.
\end{abstract}

Jpn J Phys Fitness Sports Med, 70(2): 139-148 (2021)

Keywords : cycling exercise, supplementation, oxidative stress markers, carbohydrate and lipid metabolism

緒言

運動時は骨格筋の酸素需要が増大することで，酸素摂 取量が安静時の10-15倍に増加すると報告されており ${ }^{1)}$, 活性酸素種（Reactive oxygen species：ROS）の生成が 増加する. ROSは，異物の除去などの免疫作用に寄与す

*Correspondence: m.miyashita@waseda.jp
る一方で, 酸化的傷害による幅広い機能障害を引き起こ すことが知られており，臨床的には老化や生活習慣病 などの様々な病態に関わっていると考えられている2,3. しかし生体には抗酸化能力が備わっており, 抗酸化能力 は，生体内でレドックス状態の恒常性抢よび免疫機能の 維持に作用することから ${ }^{4)}$, ROS と抗酸化能力のバラン スのことを酸化ストレスと定義されている ${ }^{3)}$.

運動により誘発されるROS増大による酸化ストレス 
の曝露は, アスリートのコンディショニングおよび運動 パフォーマンスへ影響を及ぼすと推測されている5)。一 方で急性運動㧍よび継続的な運動トレーニングにより抗 酸化能力が向上することも報告されている ${ }^{6,7)}$. 以上のこ とから，急性運動揖よび継続的な運動トレーニングによ り生体はROSに曝露されるが, 同時に運動への適応によ り抗酸化能力を獲得すると考えられている.

ROSへの適度な曝露は抗酸化能力の獲得につながる が, 過度な曝露はデオキシリボ核酸や脂質, タンパク質 の過酸化により組織傷害を引き起こすため ${ }^{3)}$, 対策とし て抗酸化作用を持つとされる成分を含むサプリメントの 摂取が挙げられる。抗酸化物質の摂取は，筋損傷の抑 制, 運動パフォーマンスの改善, 酸化ストレスの予防ま たは軽減に働くことで，激しい運動がアスリートにもた らす傷害拉よび疾病リスクを下げることに有用であると 考えられている ${ }^{7}$. 抗酸化作用が認められているビ夕ミ ンCやポリフェノールを含むサプリメントを摃取するこ とで, 運動により増加する酸化ストレスマーカーを低減 すると示唆されている ${ }^{8.9)}$. また，ミネラルの摂取は抗酸 化能力の向上へ関与すると考えられている. 銅や亜鉛は, スーパーオキシドディスムターゼの補因子として働き, 運動誘発性酸化ストレスの低減に対し有用であると報告 されている反面，有害であるという報告もあり，未だ検 討が必要である ${ }^{10)}$ ，その他，ミネラルの一種である硫黄 は抗酸化作用へ関与すると考元られている。含硫アミノ 酸のシステインや，システインを含むグルタチオンは， 構造中のチオール基 $(-\mathrm{SH}) に よ り$ 生体内で抗酸化作用 を示すことが報告されておりり ${ }^{11,12)}$ ，硫黄化合物のメチル スルホニルメタンを運動前に摂取しその影響を検討した 研究では, 運動後 24 時間まで抗酸化作用が方進すること が報告されているが13)，ミネラル含有サプリメントの急 性的な効果を検討した研究は限定されている。運動誘発 性酸化ストレスに対する有用性をさらに検討する必要が ある。一方，ミネラルは抗酸化作用へ関与するだけでな く, 脂質代謝へも影響する可能性が示唆されており, カ ルシウム摂取量の増加により, 貯蔵脂肪の分解が充進す ることで血中の遊離脂肪酸が増加する可能性が示唆され ていることから ${ }^{14)}$, 糖・脂質代謝についても着目し検討 する必要がある。

そこで本研究では, 血液マーカーを用いて運動前のミ ネラルを含むサプリメントの摂取が酸化ストレスおよび 糖・脂質代謝の応答に及ぼす影響について明らかにする ことを目的とした。ミミネラルを含むサプリメントの摂取 により酸化ストレスの上昇が抑制され，運動中の脂質代 謝が充進するという仮説を立てた。

\section{方法}

対象者 対象者は, 早稲田大学に属する大学生および大
学院生の健常男性 12 名とした. 本研究は, ヘルシンキ宣 言を尊重し，対象者の人権抢よび利益の保護に配慮した 研究計画を行い, 早稲田大学研究倫理委員会の承認（承 認番号：2017-211）を得て実施した，対象者にはあらか じめ研究の目的，方法扔よび実験に伴う苦痛および危険 性について十分な説明を行い，書面にて参加に対する同 意を得た。対象者の身体特性は，年齢 $22.5 \pm 2.4$ 歳，身 長 $173.7 \pm 5.2 \mathrm{~cm}$, 体重 $69.1 \pm 7.4 \mathrm{~kg}$, 体格指数 $22.9 \pm 1.7$ $\mathrm{kg} / \mathrm{m}^{2}$, 最大酸素摂取量 $46.1 \pm 6.1 \mathrm{~mL} / \mathrm{min} / \mathrm{kg}$ (すべて平 均土標準偏差) であった。

実験デザイン 本試験の実施前に, 本試験での運動負荷 を決定するため, 最大酸素摂取量の測定を実施した。測 定は呼気ガス分析装置（Quark CPTE, COSMED）㧍よ び自転車エルゴメーター (Ergomedic 874E, MONARK) を用いて，段階的に負荷量を増加させて測定した。ペダ リング回数は60 rpmに固定し, 疲労困供に至るまで負 荷を漸増させた。測定中，心拍計（RCX3, Polar）を用い て心拍数を測定した.

本試験はサプリメント試行とプラセボ試行の 2 試行 を，一重盲検クロスオーバー比較試験にて実施した。試 行間は 1 週間以上の間隔を空けて実施した。対象者に, 本試験前日は激しい運動の実施およびアルコール類の摂 取を控えるよう依頼した。本試験当日の血液項目への影 響を考慮し， 2 試行の前日の身体活動量を活動量計（ラ イフレコーダーEX, スズケン）にて測定し，また前日の 食事を 2 試行で統一するよう依頼した。

実験プロトコル 実験プロトコルをFig. 1に示した。対 象者は空腹にて来室後, 身長と体重を測定し, 10 分間座 位安静を保った，その後 1 分間でミネラルを含むサプリ メント 3 粒もしくはプラセボ 3 粒を水 $200 \mathrm{~mL} と と に$ 摂取した，そして事前の運動負荷試験によって得られた 安静時㧍よび最高心拍数からカルボーネン法を用いて 算出した心拍予備能の $75 \%$ 相当の強度で 60 分間の自転 車運動を行い, 運動終了後は 90 分間座位安静を保った。 サプリメント摂取前（０分），60分の運動終了直後（60 分), 運動終了 30 分後 (90分), 運動終了60 分後 (120分) 拈よび運動終了 90 分後（150分）の計 5 回, 真空採血管 を用いて, 対象者の上腕静脈より血液を採取した。また, 血液の採取と同じ時間带に, 視覚的アナログスケール （Visual analog scale：VAS）を用いて全身，上肢掞よび 下肢の主観的疲労度の評価を行った、VASは, $100 \mathrm{~mm}$ の水平線の左端を「まったく疲れていない」, 右端を「す ごく疲れている」として, 対象者が現状を垂線で記入した。 まったく疲れていない状態を 0 として, 記入された垂線 までの長さを測定し，その長さを值 $(\mathrm{mm})$ とした ${ }^{15)}$ 。心 拍数は 60 分間の運動中, 連続的に測定し， 5 分ごとの 
平均值を解析に用いた。 60 分間の運動中の自覚的運動強 度は，5分ごとにボルグスケール ${ }^{16)}$ を用いて全身および 下肢の自覚的運動強度を評価した。

試験食品 サプリメント試行では, 市販品であるドク ターズ BAPミネラル（株式会社ウイスマー）を用いた。 摂取量に関して，1日4粒と1日あたりの捸取量が規定 されており，実験に参加する対象者に対する製品摂取の 安全面の配慮から，1日の上限摂取個数未満の 3 粒とし た. プラセボ試行では, 食品カプセルNo.3（小林カプセ ル株式会社）と砂糖より作成したプラセボを用いた。サ プリメント試行の試験食品 3 粒分の栄養成分は, エネル ギー $0.96 \mathrm{kcal}$, たんぱく質 $0.15 \mathrm{~g}$, 脂質 $0.00 \mathrm{~g}$, 炭水化物 $0.11 \mathrm{~g}$, ナトリウム $23.9 \mathrm{mg}$, カルシウム $88.5 \mathrm{mg}$, カリ ウム $23.4 \mathrm{mg}$, 硫黄 $13.4 \mathrm{mg}$ であった. プラセボ試行の試 験食品 3 粒分の栄養成分は, エネルギー $3.58 \mathrm{kcal}$, たん ぱく質 $0.14 \mathrm{~g}$, 脂質 $0.00 \mathrm{~g}$, 炭水化物 $0.78 \mathrm{~g}$, ナトリウム 0.22 $\mathrm{mg}$, カルシウム $0.00 \mathrm{mg}$, カリウム $0.00 \mathrm{mg}$ であった.

血液検査項目 採取した血液を遠心分離して得られた血 清を用いて, 酸化ストレス関連指標として, 活性酸素代 謝物 (Derivatives of reactive oxygen metabolites : $d-$ ROMs) および抗酸化能力 (Biological antioxidant potential : BAP）を測定した。糖・脂質代謝関連指標として,
グルコース, 中性脂肪, 遊離脂肪酸およびインスリンを 測定した。また，筋疲労関連指標として，クレアチンキ ナーゼを測定した。

$\mathrm{d}-\mathrm{ROMs}$ 拈よびBAPは，フリーラジカル解析装置 （FREE Carrio Duo, 株式会社ウイスマー）を用いて測 定した。活性酸素により, 生体内で脂質やたんぱく質, ヌクレオチドなどの様々な物質が過酸化され, 細胞内で ヒドロペルオキシドが産生される。d-ROMs測定は, dROMsテストキット（株式会社ウイスマー）を用いて測 定した. d-ROMs 測定は血清内で呈色反応を引き起こさ せ， $505 \mathrm{~nm}$ の吸光度の変化量を計算することでヒドロ ペルオキシド濃度を算出し, 生体内の酸化ストレス度合 を総合的に評価するものである ${ }^{17,18)}$. BAP測定は, BAP テストキット（株式会社ウイスマー）を用いて測定した。 BAP 測定は血清内で呈色反応を引き起こさせ， $505 \mathrm{~nm}$ の吸光度の変化量を計算することで, 血清中の三価鉄イ オンを二価鉄イオンへ還元する力を反映しており，保持 する還元作用を総合的に評価するものである ${ }^{17,19)}$.

インスリンは, 酵素免疫測定法にて測定を行い, ヒ トインスリン測定キット (Insulin, Human, ELISA Kit, Mercodia）およびプレートリーダー（Sunrise Remote, Tecan Austria GmbH) を用いた. グルコース, 中性脂肪, 遊離脂肪酸, クレアチンキナーゼの測定は, 株式会社江 東微生物研究所に依頼した。グルコースは酵素法にて測
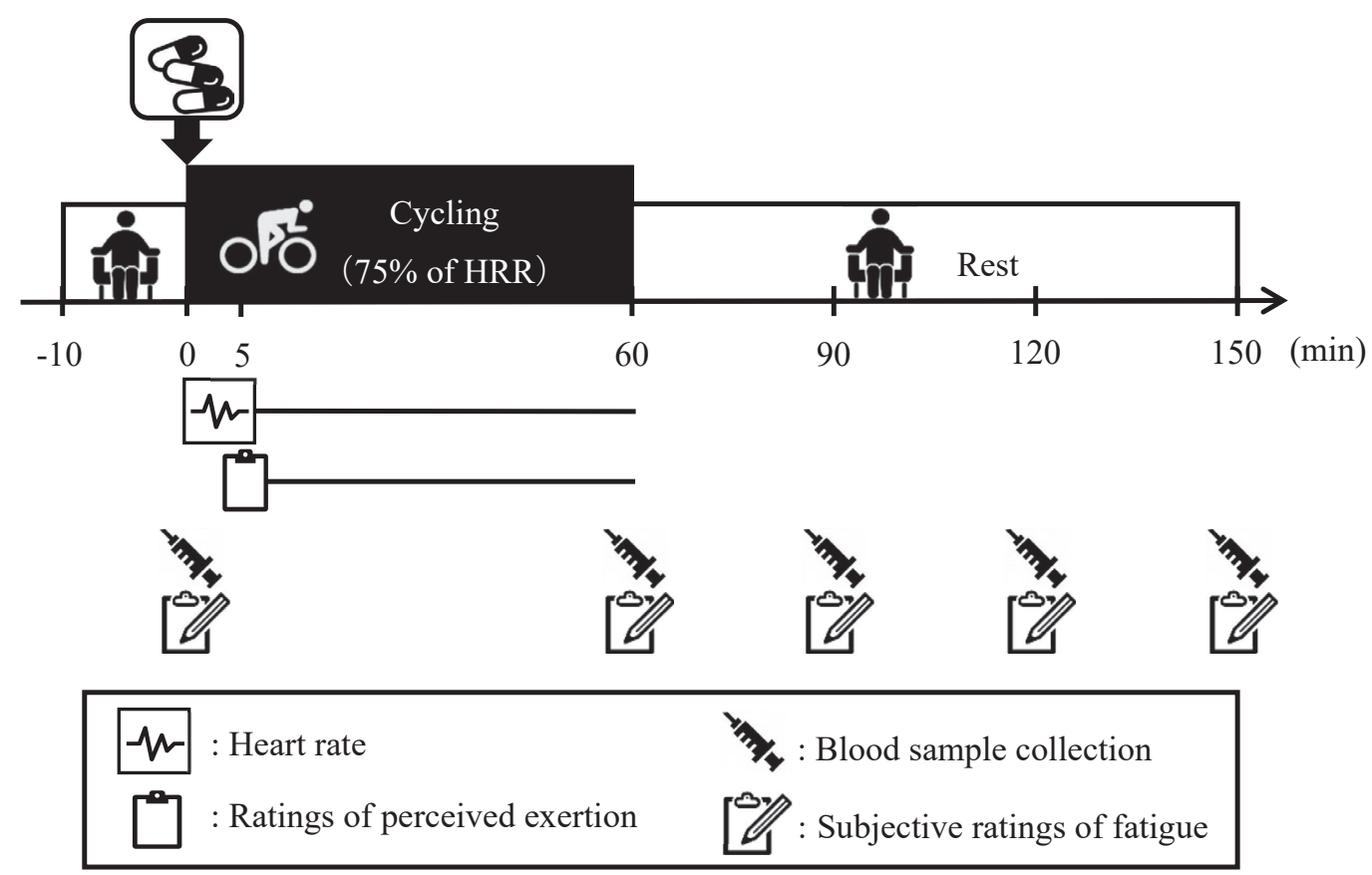

Fig. 1 A schematic representation of the study protocol.

The participants rested in a chair for 10 minutes after arriving the laboratory in the supplementation and placebo trials. Then, participants consumed either mineral-containing antioxidant supplements (i.e., the supplementation trial) or placebo supplements (i.e., the placebo trial). Thereafter, participants performed cycling exercise at $75 \%$ of heart rate reserve (HRR) for 60 minutes in both trials. Participants then rested in the laboratory for 90 minutes in both trials. 
定を行い, 試薬（LタイプワコーGlu2, 富士フィルム和 光純薬株式会社) および自動分析装置（JCA-BN8060, 日 本電子株式会社）を用いた。遊離脂肪酸は酵素法にて検 査を行い, 試薬（NEFA-HR II, 富士フィルム和光純薬 株式会社）および自動分析装置（JCA-BM8060, 日本電 子株式会社）を用いた。 クレアチンキナーゼはJSCC 標 準化対応法にて測定を行い, 試薬（Lタイプワコー CK, 富士フィルム和光純薬株式会社）抒よび自動分析装置 （JCA-BM8060, 日本電子株式会社）を用いた。

d-ROMs，BAP，インスリン, グルコース，中性脂肪， 遊離脂肪酸およびクレアチンキナーゼの測定における変 動係数はそれぞれ, $1.70 \%, 2.30 \%, 0.25 \%, 0.59 \%, 1.39 \%$, 0.96\%，0.71\%であった。

統計処理 本研究で得られた結果は全て平均值士標準偏 差で示した。全ての統計処理には統計解析ソフト (SPSS Statistics version 22, IBM）を用いた，両試行に扔ける前 日の身体活動量の比較は, 対応のある $\mathrm{t}$ 検定を用いて検 定した。また，試行と時間を要因とした評価項目（主観 的運動強度, 心拍数, 主観的疲労度㧍よび血液検查項目) の変化について，二元配置の分散分析を用いて検定した． 二元配置の分散分析において交互作用が認められた項目 については, Bonferroniの調整による多重比較を行った。 なお，運動前安静時の值でばらつきが見られた中性脂肪 とクレアチンキナーゼに抒いては，サプリメント摂取前 （0 分）の值を基準として変化量を算出し, 統計解析を 行った。検定の有意水準は危険率 $5 \%$ 未満とした。

\section{結果}

本試験前日の身体活動量 本試験前日の歩数に関して サプリメント試行 $8,085 \pm 5,567$ 歩/日，プラセボ試行 6,596 土2,980歩/日であり，試行間に差は認められなかった $(\mathrm{p}=0.378)$. 活動量計の装着時間で補正した歩数に関し て，サプリメント試行 $12.4 \pm 8.4$ 歩/日・分，プラセボ試 行 $11.7 \pm 6.0$ 歩/日・分であり，試行間に差は認められな かった（ $\mathrm{p}=0.691 ）$.中強度以上の身体活動時間に関し て，サプリメント試行 $30.9 \pm 27.0$ 分/日，プラセボ試行 $28.1 \pm 19.0$ 分/日であり，試行間に差は認められなかった $(\mathrm{p}=0.646)$.

酸化ストレス関連指標 d-ROMs と BAPの経時的変化 をFig. 2 に示した。 d-ROMsに関して，時間の主効果を 認めた一方で $(\mathrm{p}<0.001)$, 試行の主効果 $(\mathrm{p}=0.250)$ お よび試行と時間の交互作用（ $\mathrm{p}=0.075 ）$ は認められな かった，BAPに関して，時間の主効果を認めた一方で $(p=0.005)$ ，試行の主効果 $(p=0.390)$ および試行と時間 の交互作用（ $\mathrm{p}=0.937 ）$ は認められなかった.

糖・脂質代謝関連および筋疲労関連指標 血中グルコー 久濃度, インスリン濃度, 中性脂肪濃度, 遊離脂肪酸濃 度およびクレアチンキナーゼ濃度の経時的変化を Table 1に示した。グルコース，インスリンおよびクレアチン キナーゼに関して，各々時間の主効果を認めた一方で $(\mathrm{p}<0.001, \mathrm{p}=0.002, \mathrm{p}<0.001)$ ，試行の主効果および試 行と時間の交互作用は認められなかった。遊離脂肪酸は, 時間の主効果（ $\mathrm{p}<0.001 ）$ および試行と時間の交互作用 （p=0.036）が認められた。多重比較の結果，60分の運動 終了直後 $(60$ 分) のサプリメント試行 $(1.1 \pm 0.5 \mathrm{mmol} / \mathrm{L})$ で,プラセボ試行と比較し $(0.9 \pm 0.3 \mathrm{mmol} / \mathrm{L})$ 高值を示 した $(p=0.024)$

運動中の自覚的運動強度および心拍数＼cjkstart運動中の自覚的 運動強度と心拍数について 5 分ごとの平均值をTable 2 に示した。全身㧍よび下肢の自覚的運動強度に関して,
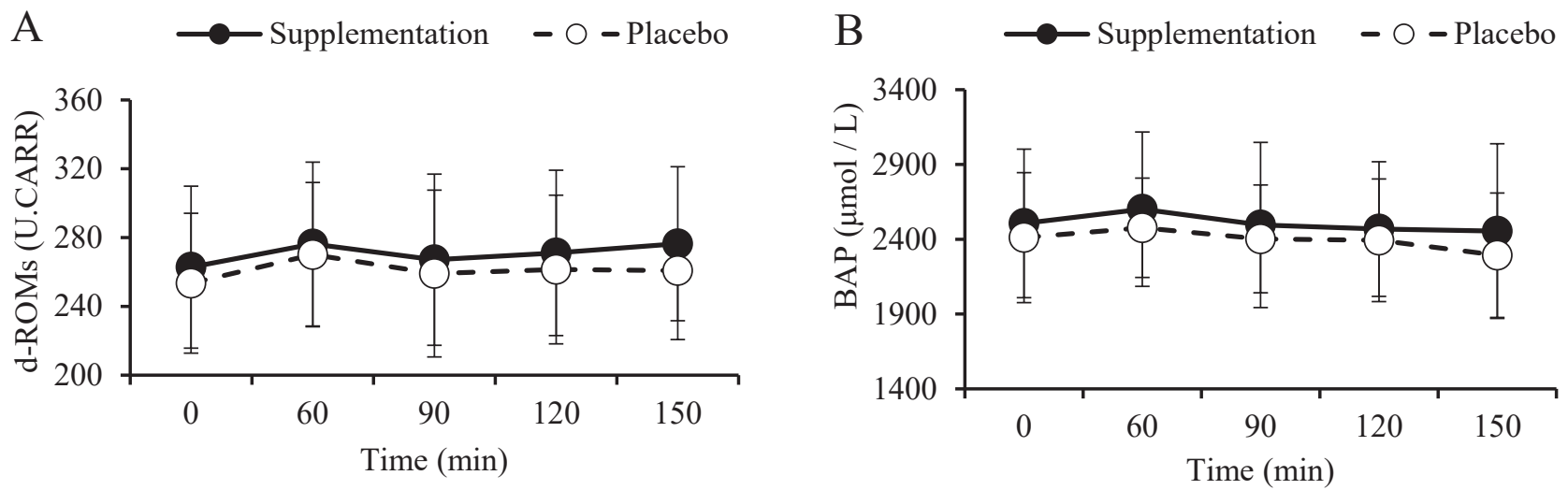

Fig. 2 Serum concentrations of derivatives of reactive oxygen metabolites (d-ROMs) (A) and biological antioxidant potential (BAP) (B) during the supplementation and placebo trials.

Data are means \pm SD for $n=12$. Data were analysed using 2 -factor ANOVA with repeated measures. There was a main effect of time $(p<0.001$ for $\mathrm{d}-\mathrm{ROMs}$ and $\mathrm{p}=0.005$ for BAP). 


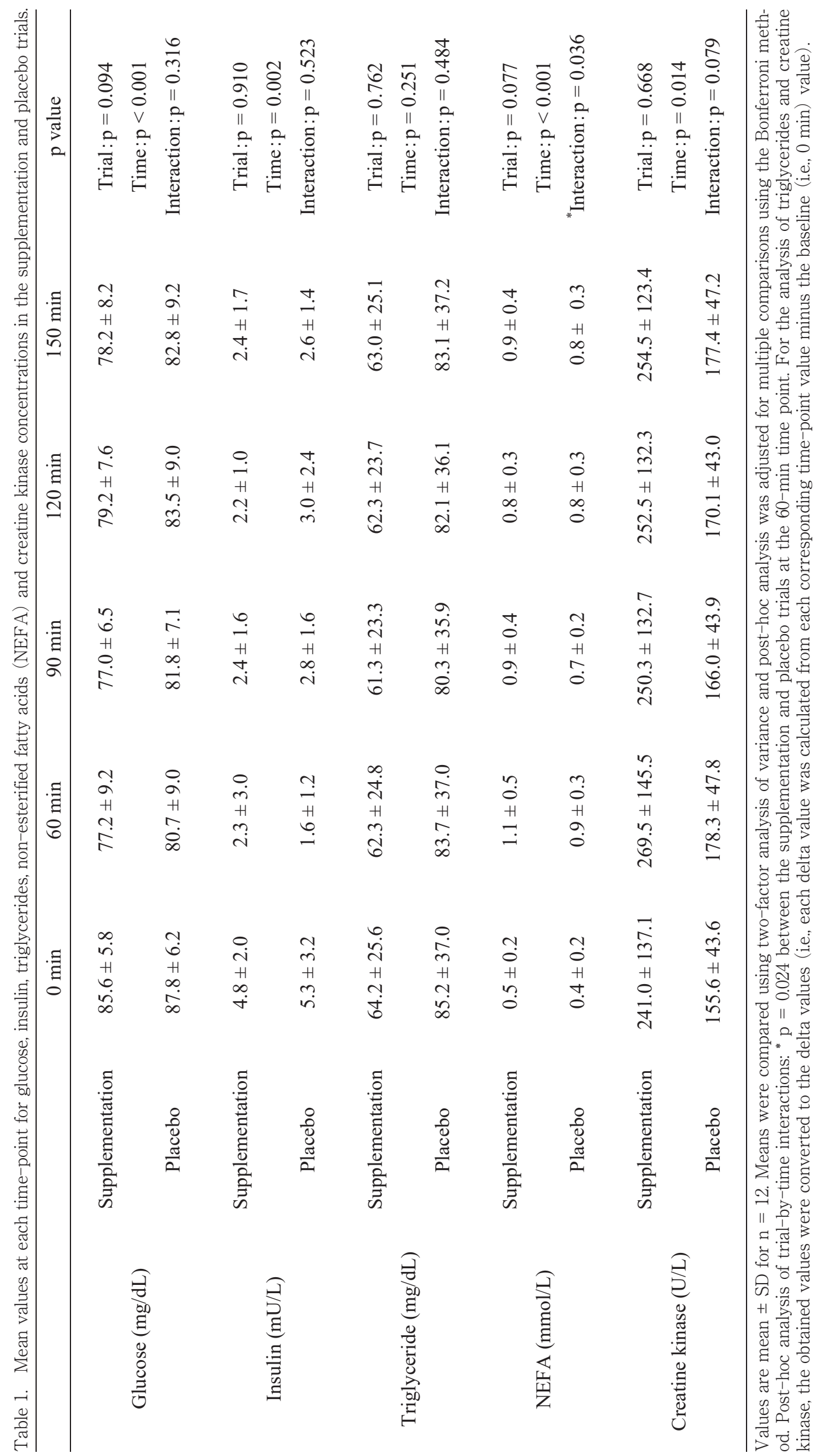


各々時間の主効果（ $\mathrm{p}<0.001, \mathrm{p}<0.001 ）$ を認めた一方で, 試行の主効果抢よび試行と時間の交互作用は認められな かった。 心拍数に関して, 時間の主効果 $(\mathrm{p}=0.042)$ を認 めた一方で，試行の主効果および試行と時間の交互作用 は認められなかった。

主観的疲労度 サプリメント摂取前（0 分)，60分の運 動終了直後 (60 分), 運動終了 30 分後 (90分), 運動終 了60分後（120分）㧍よび運動終了90分後（150分）の 主観的疲労度をTable 3 に示した。全身，上肢，下肢 の全ての項目に関して，時間の主効果を認めた一方で $(\mathrm{p}<0.001, \mathrm{p}<0.001, \mathrm{p}<0.001)$, 試行の主効果および試行 と時間の交互作用は認められなかった。

\section{考察}

本研究では, 運動前のミネラルを含むサプリメントの 摂取が酸化ストレスならびに糖・脂質代謝応答に及ぼす 影響について検討するため, ミネラルサプリメントまた はプラセボサプリメント摂取前から 60 分間の運動後 90 分間までの150分間にわたって血液を採取し測定を行っ た，本研究の結果より，ミネラルサプリメントの摂取 による酸化ストレス関連指標であるd-ROMsならびに BAPへの影響は認められなかった。また，ミネラルを含 むサプリメントの摂取により, 運動時の脂質代謝へ関与 する可能性が示唆された.

活性酸素代謝物の指標である d-ROMs の正常範囲は 200-300 U.CARR と定義されている ${ }^{18)}$ 。本研究では, 全 測定を通してd-ROMsの平均值は正常範囲内であり，仮 説に反して試行間に有意な差は認められなかった。抗酸 化能力の指標であるBAPも全測定を通して試行間に有 意な差は認められなかった。 BAPの最適範囲は2,200$2,400 \mu \mathrm{mol} / \mathrm{L}$ とされているが ${ }^{19)}$ ，本研究のBAPは全測 定を通して $2,200 \mu \mathrm{mol} / \mathrm{L}$ を回り高值を示した。これに は体力および身体活動レベルが関連していた可能性が考 えられる. 先行研究において, 鍛錬者は中強度の運動後 90分までは酸化ストレスが上昇しないこと ${ }^{5)}$, 習慣的に トレーニングを行っている鉎錬者は, 座りがちな習慣を もつ健常者よりも抗酸化酵素レベルが高いことが示唆さ れている ${ }^{7)}$. 本研究の対象者の最大酸素摂取量は $46.1 \pm$ $6.1 \mathrm{~mL} / \mathrm{min} / \mathrm{kg}$ と本邦の身体活動ガイドラインで示され ている同年代の基準值よりも高く ${ }^{20)}$ ，運動習慣について 12 名中 10 名が，1 週間に 2 回以上, 1 回 30 分以上, 中. 高強度の定期的な身体活動を行う運動習慣者であった。 このことから, 本研究で 60 分間の運動後にd-ROMsが 正常範囲を逸脱しなかった要因として, 対象者の全身持 久力および身体活動レベルが一定の基準以上であり抗酸 化能力が高かったことが関連していたと考えられる。

本研究で用いたミネラルを含むサプリメントのうち,
抗酸化能力に影響を及ぼすと考えられるのが硫黄であ る。硫黄の水素化合物である硫化水素は, 過酸化水素や スーパーオキシドの直接除去へ働くことや，抗酸化防 御システムのアップレギュレーションを起こすことか ら，抗酸化作用へ関与すると動物実験より報告されてい $~^{21)}$ ， しかし硫化水素は元来有毒ガスであり，ヒ卜を対 象とした研究は検討されておらず，硫黄関連サプリメン トの摂取と運動誘発性酸化ストレスについてのヒト研究 の多くは，硫黄を主成分とした栄養補助食品であるメチ ルスルホニルメタンサプリメントを用いている。体重 $1 \mathrm{~kg}$ 当たり $100 \mathrm{mg} / \mathrm{kg}$ のメチルスルホニルメタンサプ リメントを摂取した 2 時間後に，最大酸素摂取量の $75 \%$ の強度でトレッドミル走を行った際のサプリメントの急 性効果について検討した先行研究では, 運動後24時間ま で抗酸化作用の上昇がみられたと報告している ${ }^{13)}$ 。また メチルスルホニルメタンサプリメントの継続摂取による 慢性効果を検討した研究では，30日間メチルスルホニ ルメタンサプリメントを 1 日当たり $3.0 \mathrm{~g} /$ 日継続摂取す ると抗酸化作用が増加したと報告している ${ }^{22)}$ 。この機序 として, メチルスルホニルメタンサプリメントの摂取 が，NF-kBの転写活性を阻害することで，ROS産生に 関与する酵素やサイトカインの発現を抑制するためであ $b^{23)}$. 本研究の仮説に反して本研究で試行間の差が認め られなかった要因として2つ考えられる。1つ目は，サ プリメントの硫黄含有量である。先行研究で用いられた メチルスルホニルメタンサプリメントの硫黄含有量は, 急性効果の検討では $34.0 \mathrm{mg} / \mathrm{kg}$, 慢性効果の検討では $1022.1 \mathrm{mg} /$ 日であった ${ }^{13,22)}$. しかし, 本研究で用いたミ ネラルサプリメントに含まれる硫黄含有量は全体量とし て13.4 mgであったことから，生体の酸化ストレス応答 に影響を与えるには硫黄含有量が不足していた可能性が 考えられる。しかし, 本研究では摂取したサプリメント における血中の硫黄濃度を測定しておらず，メチルスル ホニルメタンサプリメントと本研究で用いたミネラルを 含むサプリメントの摂取による生体への影響を単純に比 較することは難しい，2つ目は，摂取のタイミングであ る。メチルスルホニルメタンサプリメントの急性効果が 認められたNakhostin-Roohi らの研究では運動 2 時間前 にサプリメントを摂取しているが13)，一方で本研究では 運動直前に摂取している。先述したとおり，本研究では 摂取後の血中の硫黄濃度を測定していないため, サプリ メントの成分が体内へ吸収ならびに代謝されたかは不明 であるが，血中の硫黄濃度の上昇が不十分であったこと が可能性として考えられる。ささらに，本研究のミネラル を含むサプリメントは, 先行研究とは成分が異なる上に, 抗酸化作用を引き起こすメカニズムが異なる可能性もあ るため, 酸化ストレスに影響を示す硫黄の摂取量ならび に摂取タイミングについて，検討が必要である。 


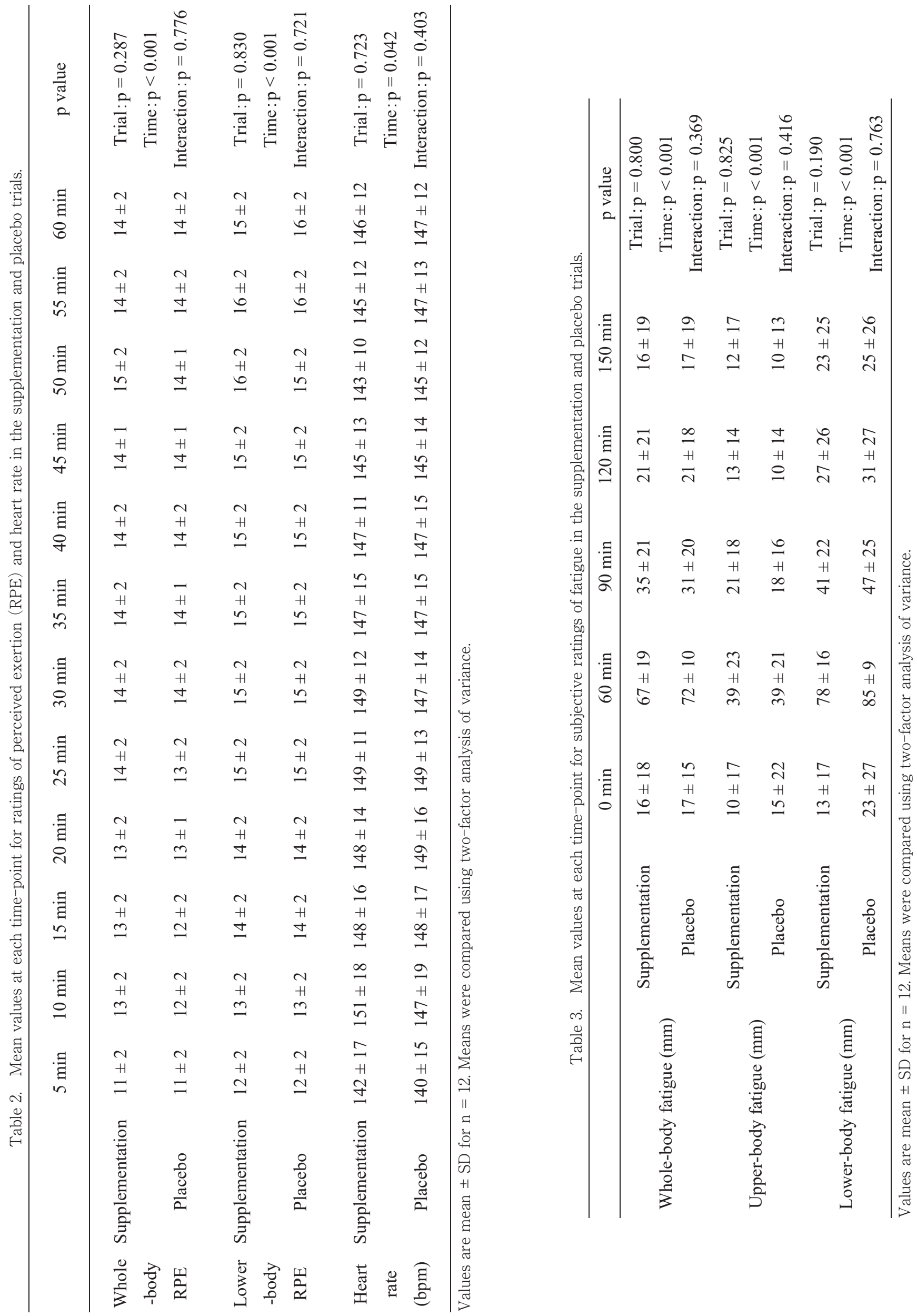


本研究のもうひとつの主眼点である糖・脂質代謝につ いて, 遊離脂肪酸濃度が運動直後にプラセボ試行と比較 してサプリメント試行において高值を示した（Table 1). この差異について, 要因は 2 つ考えられる。1つ目は硫 化水素と脂質代謝の関連性である。硫化水素は膵臓の $\beta$ 細胞において, 生体に貯蔵されている含硫アミノ酸を基 質として，シスタチオニン $\beta$ 合成酵素やシスタチオニン $\gamma$ リアーゼによって合成されるが ${ }^{12}$ ， ラットの副腎髄質 クロム親和性細胞に扔いて，この硫化水素合成酵素の発 現があり，低酸素刺激によりカテコラミンや硫化水素の 放出が誘発される可能性が報告されている ${ }^{24)}$.さらに, 外因性の硫化水素が，ラットの副腎髄質クロム親和性細 胞からのカテコラミン放出を直接刺激することが示され ている ${ }^{25)}$.このカテコラミンは脂肪分解を調節する要素 のひとつであり， $\beta$-アドレナリン受容体に作用するこ とで脂肪細胞内の $\mathrm{cAMP}$ 濃度を上昇させる。 そしてプロ テインキナーゼ Aの活性化によりホルモン感受性リパー ゼをリン酸化および活性化することで, 結果的に脂肪分 解が充進されることが知られている ${ }^{26)}$ ，このことから， 本研究に抢ける遊離脂肪酸濃度の上昇は, 内因性抢よび サプリメント摂取による外因性の硫化水素によりカテコ ラミン分泌が充進することで, 脂肪分解が充進した可能 性が考えられる．2つ目はカルシウムの作用が考えられ る。絶食状態でカルシウム摂取が増加すると, 貯蔵され ている脂肪の分解の充進により遊離脂肪酸が増加する可 能性が示唆されている ${ }^{14)}$ 。 また，肥満マウスを用いた研 究において, 脂肪細胞内に打ける細胞内カルシウムの増 加を刺激することでカルシウム摂取により脂肪分解が立 進することが報告されている27)。このことから，サプリ メントに含まれるカルシウムが脂肪分解へ関与し遊離脂 肪酸濃度の上昇へ働きかけた可能性がある。しかしなが ら, 本研究では脂質代謝について詳細な測定を行ってい ないため，ミネラルサプリメントの生理的な作用機序に ついて更なる検討が必要である。

全身と下肢の自覚的運動強度, VASによる主観的疲労 度㧍よび心拍数について, 試行間に差は認められなかっ た。このことから，対象者にとって両試行は同等の運動 負荷であったと考えられ，運動前の単回のミネラルを含 むサプリメント摂取は主観的な運動強度, 疲労度および 心拍数に影響を与えないことが示唆された.VASによる 主観的疲労度について試行間に差は認められなかったも のの, 先行研究 ${ }^{28,29)}$ と同様に両試行ともに運動直後に高 值，運動30分後以降は低值を示しており，自覚的な疲労 度を伴う運動強度であった。これはd-ROMs 值が両試行 において運動直後に高值を示したことからも推察される。

最後に, 本研究の酸化ストレスマーカーとして用い たd-ROMsならびにBAPは生体内の酸化ストレスなら びに抗酸化能力をそれぞれ総合的に評価する指標であ
る $^{17-19)}$. しかし，ROSや抗酸化物質には多くの種類があ り，ROSにはヒドロキシルラジカルやスーパーオキシド などのフリーラジカルと, 一重項酸素や過酸化水素, ヒ ドロペルオキシドなどの非ラジカルの活性酸素に大別さ れる ${ }^{30)}$ ，酸化ストレス指標として，これらのROSを直接 的に評価した研究もあれば8,31)，ROSによる反応生成物 であるマロンジアルデヒドを測定して間接的に評価して いる研究や 5 ,8,32-35)，デオキシリボ核酸の酸化指標として 尿中 8 -ヒドロキシーデオキシグアノシンを測定した研

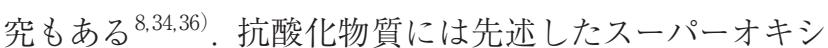
ドディスムターゼ，グルタチオンペルオキシダーゼおよ びカタラーゼだけでなく, 酸化型グルタチオン, 還元型 グルタチオンおよびグルタチオンレダクターゼなどが挙 げられ，抗酸化能力の指標として用いられている8 ${ }^{8,33,37-39)}$. 一方で, 複数の評価指標を同一の研究内で検討したと しても，全ての項目に招いて同じ応答はみられないう えに ${ }^{38)}$ ，産生したROSや抗酸化物質を特定することは 難しく, 各々の指標を詳細に測定し検討するためには時 間的ならびに金銭的な限界があることに留意する必要が ある。

\section{結論}

本研究の結果から，ミネラルを含むサプリメントの摂 取による酸化ストレスマーカーへの影響は認められな かった。また，サプリメントに含まれる硫黄やカルシウ ムが, 運動時の脂質代謝へ関与する可能性が示唆された。

利益相反自己申告 : 著者全員に扔いて利益相反はない．

\section{著者貢献}

著者 $\mathrm{SN}$ と MM は研究デザインとプロトコルを概念化し， 対象者を決定した。著者 $\mathrm{SN}, \mathrm{YT}, \mathrm{KK}, \mathrm{CN}$ と $\mathrm{YH} は$ ばー夕 の整理・分析および解釈を担当した。草稿は著者 $\mathrm{SN}$ が担当 した。著者 $\mathrm{CN}$ と $\mathrm{MM}$ は原稿を批評し編集校正を担当した。 すべての著者は, 最終原稿を熟読した上で, 投稿を承認した。

\section{引用文献}

1) Sen CK. Antioxidants in exercise nutrition. Sports Med 31: 891-908, 2001. doi: 10.2165/00007256-20013113000001.

2）江口裕伸, 藤原範子, 大河原知水, 鈴木敬一郎, 谷口直之： 酸化ストレスと健康, 生物試料分析, 32: 247-256, 2009.

3）大石修司：運動と酸化ストレス-活性酸素と抗酸化防 御のバランスの重要性-, 国立医療学会誌, 69: 317-324, 2015.

4) Lee S, Hashimoto J, Suzuki T, Satoh A. The effects of exercise load during development on oxidative stress levels and antioxidant potential in adulthood. Free Radic Res 51: 179-186, 2017. doi: 10.1080/10715762.2017.1291939. 
5）長島未央子：長時間自転車運動が鍛錬者の酸化ストレ ス度及び血中ビタミン濃度におよぼす影響, 体力科学, 60: 279-286, 2011. doi: 10.7600/jspfsm.60.279.

6) Parker L, Mcguckin TA, Leicht AS. Influence of exercise intensity on systemic oxidative stress and antioxidant capacity. Clin Physiol Funct Imaging 34: 377-383, 2014. doi: 10.1111/cpf.12108.

7) Pingitore A, Lima GP, Mastorci F, Quinones A, Iervasi G, Vassalle C. Exercise and oxidative stress: Potential effects of antioxidant dietary strategies in sports. $\mathrm{Nu}$ trition 31: 916-922, 2015. doi: 10.1016/j.nut.2015.02.005.

8) Urso ML, Clarkson PM. Oxidative stress, exercise, and antioxidant supplementation. Toxicology 189: 4154, 2003. doi: 10.1016/S0300-483X (03)00151-3.

9) Myburgh KH. Polyphenol supplementation: Benefits for exercise performance or oxidative stress? Sports Med 44: S57-70, 2014. doi: 10.1007/s40279-014-0151-4.

10) Yavari A, javadi M, Mirmiran P, Bahadoran Z. Exercise-induced oxidative stress and dietary antioxidants. Asian J Sports Med 6: e24898, 2015. doi: 10.5812/asjsm.24898.

11) Ida $T$, Sawa $T$, Ihara $H$, Tsuchiya $Y$, Watanabe $Y, K u-$ magai Y, Suematsu M, Motohashi H, Fujii S, Matsunaga T, Yamamoto M, Ono K, Devarie-Baez NO, Xian M, Fukuto M, Akaike T. Reactive cysteine persulfides and S-polythiolation regulate oxidative stress and redox signaling. Proc Natl Acad Sci U S A 111: 76067611, 2014. doi: 10.1073/pnas.1321232111.

12）居原秀：活性イオウ分子による細胞毒性の調節機 構, 日本薬理学雑誌, 147: 290-293, 2016. doi: 10.1254/ fpj.147.290.

13) Nakhostin-Roohi B, Niknam Z, Vaezi N, Mohammadi $\mathrm{S}$, Bohlooli S. Effect of single dose administration of methylsulfonylmethane on oxidative stress following acute exhaustive exercise. Iran J Pharm Res 12: 845853, 2013. doi: 10.22037/ijpr.2013.1357.

14）青江誠一郎：乳製品あるいはカルシウム摂取が体重お よび体組成に及ぼす影響, ミルクサイエンス, 57: 1-12, 2008. doi: 10.11465/milk.57.1.

15) Williamson A, Hoggart B. Pain: A review of three commonly used pain rating scales. J Clin Nurs 14: 798-804, 2005. doi: 10.1111/j.1365-2702.2005.01121.x.

16）小野寺孝一, 宮下充正：全身持久性運動における主観 的強度と客観的強度の対応性 : Rating of perceived exertionの観点から, 体育学研究, 21: 191-203, 1976. doi: 10.5432/jjpehss.KJ00003405473.

17）永田勝太郎, 長谷川拓也, 広門靖正, 喜山克彦, 大槻千佳： 生活習慣病と酸化ストレス防御系, 心身医学, 48: 177183, 2008. doi: 10.15064/jjpm.48.3_177.

18）関 泰一：d-ROMSテストによる酸化ストレス総合評価, 生物試料分析, 32: 301-306, 2009 .

19) Sugita M, Kapoor MP, Nishimura A, Okubo T. Influence of green tea catechins on oxidative stress metabolites at rest and during exercise in healthy humans. Nutrition 32: 321-331, 2016. doi: 10.1016/ j.nut.2015.09.005.

20）厚生労働省：健康づくりのための身体活動基
準 2013, 2013. https://www.mhlw.go.jp/stf/ houdou/2r9852000002xple-att/2r9852000002xpqt.pdf （閲覧日 2020年 5 月 13 日）

21) Xiao Q, Ying J, Xiang L, Zhang C. The biologic effect of hydrogen sulfide and its function in various diseases. Medicine (Baltimore) 97: e13065, 2018. doi: 10.1097/ MD.0000000000013065.

22) Kalman DS, Feldman S, Scheinberg AR, Krieger DR, Bloomer RJ. Influence of methylsulfonylmethane on markers of exercise recovery and performance in healthy men: A pilot study. J Int Soc Sports Nutr 9: 46, 2012. doi: 10.1186/1550-2783-9-46.

23) Butawan M, Benjamin RL, Bloomer RJ. Methylsulfonylmethane: Applications and safety of a novel dietary supplement. Nutrients 9: 290, 2017. doi: 10.3390/ nu9030290.

24) Peng YJ, Nanduri J, Raghuraman G, Souvannakitti D, Gadalla MM, Kumar GK, Snyder SH, Prabhakar NR. H2S mediates $\mathrm{O} 2$ sensing in the carotid body. Proc Natl Acad Sci U S A 107: 10719-10724, 2010. doi: 10.1073/pnas.1005866107.

25) Zhu D, Yu X, Sun J, Li J, Ma X, Yao W. H2S induces catecholamine secretion in rat adrenal chromaffin cells. Toxicology 302: 40-43, 2012. doi: 10.1016/ j.tox.2012.07.008.

26）大沼 裕, 大澤春彦, 牧野英一: 脂質分解系の調節, 糖尿病, 46: 736-738, 2003. doi: 10.11213/tonyobyo1958.46.736.

27) Teegarden D. The influence of dairy product consumption on body composition. J Nutr 135: 2749-2752, 2005. doi: 10.1093/jn/135.12.2749.

28）松田知華, 山田満月, 須永美歌子：女性アスリートにお ける月経周期が短時間高強度運動時の酸化ストレスお よび抗酸化力に及ぼす影響, 日本運動生理学雑誌, 26 : 9-18, 2019.

29）石渡智子, 森藤雅史, 石島寿道, 青山友子, 菅間 薰, 神田 和江, 鈴木克彦, 樋口 満: 運動による自覚的疲労度とス トレスホルモン・サイトカインとの関連性, 日本補完代 替医療学会誌, 8: 67-73, 2011. doi: 10.1625/jcam.8.67.

30）大野秀樹, 鈴木健二, 人見嘉哲, 木本紀代子, 伊藤長栄, 宮澤伸子, 木崎節子：運動とフリーラジカル, 体力科学, 50: 389-416, 2001. doi: 10.7600/jspfsm1949.50.389.

31) Alessio HM, Hagerman AE, Fulkerson BK, Ambrose J, Rice RE, Wiley RL. Generation of reactive oxygen species after exhaustive aerobic and isometric exercise. Med Sci Sports Exerc 32: 1576-1581, 2000. doi: 10.1097/00005768-200009000-00008.

32) Bloomer RJ, Fisher-Wellman KH. Blood oxidative stress biomarkers: influence of sex, exercise training status, and dietary intake. Gend Med 5: 218-228, 2008. doi: 10.1016/j.genm.2008.07.002.

33) Xu X, Ding Y, Yang Y, Gao Y, Sun Q, Liu J, Yang X, Wang J, Zhang J. $\beta$-glucan Salecan improves exercise performance and displays anti-fatigue effects through regulating energy metabolism and oxidative stress in mice. Nutrients 10: 858, 2018. doi: 10.3390/nu10070858.

34) Withee ED, Tippens KM, Dehen R, Tibbitts D, Hanes D, Zwickey H. Effects of Methylsulfonylmethane (MSM) 
on exercise-induced oxidative stress, muscle damage, and pain following a half-marathon: A double-blind, randomized, placebo-controlled trial. J Int Soc Sports Nutr 14: 24, 2017. doi: 10.1186/s12970-017-0181-z.

35) Miyazaki H, Oh-ishi S, Ookawara T, Kizaki T, Toshinai K, Ha S, Haga S, Ji LL, Ohno H. Strenuous endurance training in humans reduces oxidative stress following exhausting exercise. Eur J Appl Physiol 84: 1-6, 2001. doi: 10.1007/s004210000342.

36) Okamura K, Doi T, Hamada K, Sakurai M, Yoshioka Y, Mitsuzono R, Migita T, Sumida S, Sugawa-Katayama $\mathrm{Y}$. Effect of repeated exercise on urinary 8-hydroxydeoxyguanosine excretion in humans. Free Radic Res 26: 507-514, 1997. doi: 10.3109/10715769709097821.

37) Ortenblad N, Madsen K, Djurhuus MS. Antioxi- dant status and lipid peroxidation after short-term maximal exercise in trained and untrained humans. Am J Physiol 272: R1258-R1263, 1997. doi: 10.1152/ ajpregu.1997.272.4.R1258.

38) Takahashi M, Suzuki K, Kim HK, Otsuka Y, Imaizumi A, Miyashita M, Sakamoto S. Effects of curcumin supplementation on exercise-induced oxidative stress in humans. Int J Sports Med 35: 469-475, 2014. doi: 10.1055/s-0033-1357185.

39) Ristow M, Zarse K, Oberbach A, Klöting N, Birringer M, Kiehntopf M, Stumvoll M, Kahn CR, Blüher M. Antioxidants prevent health-promoting effects of physical exercise in humans. Proc Natl Acad Sci U S A 106: 8665-8670, 2009. doi: 10.1073/pnas.0903485106. 